\title{
Meat Quality Parameters and the Effects of Stress: A
}

\section{Review}

Tatiany Carvalho dos $\operatorname{Santos}^{1}$, Richard Stephen Gates ${ }^{2}$, Cecília de Fátima Souza ${ }^{1}$, Ilda de Fátima Ferreira Tinôco ${ }^{1}$, Márcia Gabrielle Lima Cândido ${ }^{1}$ and Letícia Cibele da Silva Ramos Freitas ${ }^{1}$

1. Department of Agricultural Engineering, Federal University of Viçosa, Viçosa, Minas Gerais 36570-9000, Brazil

2. Department of Agricultural and Biological Engineering, University of Illinois at Urbana-Champaign, Urbana, Illinois 61801, United States

\begin{abstract}
The objective of this review was to address the stress effects on meat quality considering the main attributes that involve meat quality. Animal protein production has been increasing with global demand for meat with meat quality a major concern, especially for more demanding consumers who are looking for quality products to meet their needs. The quality of the meat is the result of what happened to the animal throughout the production chain, that is, good rearing conditions result in a better meat quality. Different types of stress can be harmful to animals due to inadequate or improper animal handling on farms, inadequate transport conditions, poorly maintained trucks and roads, and conditions that agitate animals can lead to bruising, thermal stress. The stress in animals occurs when they are in adverse conditions and can significantly compromise meat quality loss. As an example, stress can significantly affect meat quality parameters as drip loss (DL), meat color, change ultimate $\mathrm{pH}$ and cause meat anomalies. Among the main parameters of evaluation used for meat quality are color, characterized by luminosity $\left(L^{*}, a^{*}, b^{*}\right)$, lipid and protein oxidation, $\mathrm{pH}$, water holding capacity (WHC) and softness. Producing and processing high-quality meat is a challenge since it is necessary to apply methods that promote comfort in a complete sense, in a way that minimizes inducing significant stress. Based on the results presented it is remarkable that stress alters the meat quality, compromising the main attributes that involve it, like color, $\mathrm{pH}$, WHC, Warner-Bratzler shear force (WBSF), lipid oxidation, among others andis necessary to avoid or reduce stress caused during the production of the animals to ensure a high-quality meat, resulting in greater profitability for the producer.
\end{abstract}

Key words: Animal stress, drip loss, farm buildings, meat quality, tenderness.

\section{Introduction}

Animal protein production has been increasing with global demand for meat $[1,2]$ with meat quality a major concern, especially for more demanding consumers who are looking for quality products to meet their needs $[3,4]$. Meat quality can be perceived by its sensory attributes (color, texture, juiciness, taste, odor, softness), nutritional composition (fat content, fatty acid profile, protein percentage, minerals and vitamins), technical parameters $(\mathrm{pH}$, water holding capacity (WHC) and thawing loss), absence of chemical and microbial residues (antibiotics, hormones, dioxins, Salmonella, Listeria, or other

Corresponding author: Tatiany Carvalho dos Santos, Ph.D. student, research fields: meat quality, thermal environment, thermal stress. contaminants), ethical considerations (animal husbandry, animal well-being) and, in addition, by the sustainable production aspects $[4,5]$.

Carcass traits and meat quality, such as tenderness and color, are critical for consumer acceptance [6]. Some aspects of meat quality such as color and amount of fat can be perceived visually, but others such as nutritional value and the absence of residues are only ensured by means adequate analysis and labeling and certification.

The level of stress experienced by the animal is one of the factors affecting the meat quality [7]. When subjected to stressful conditions, the meat of slow-growing chickens could be different from that of fast-growing [8]. Meat (and meat products) can deteriorate due to microbial growth and subsequent 
chemical deterioration, with the most common form of chemical deterioration being lipid and protein oxidation [9]. Deterioration may be caused when the animal is subjected to adverse conditions that lead to stress, directly influencing the meat quality. Karaca et al. [10] reported that fasting had a negative effect on some meat quality parameters, with significant increases in some physiological stress indicators after fasting periods of $24 \mathrm{~h}$ or longer on traits of lambs.

Some specific processes during the production cycle result in stress for the animal. In the process of transferring animals from farm to slaughter, stress is an inevitable consequence [11]. Pre-slaughter stress is both an animal welfare and a meat quality issue [12]. There is a direct association of meat quality with pre-slaughter management, whether on the property or while transporting animals to a slaughterhouse [12-16]. Incorrect pre-slaughter handling may cause carcasses to develop meat abnormalities such as pale, soft, exudative (PSE) or dark, firm, dry (DFD) [15].

The effects of environmental temperature on meat tenderness vary depending on temperature and duration of exposure [17]. Heat stress also decreases meat quality [6]. According to Kim et al. [18] cyclic heat stress had little impact on color, WHC, protein functionality and lipid/protein oxidation stability of ground chicken leg meat. Increased levels of stress hormones in the muscle could lead to post-mortem metabolic/structural modifications that could be reflected on meat quality [19]. The objective of this review was to address the stress effects on meat quality considering the main attributes that involve meat quality.

\section{Stress Factors That Affect Meat Quality}

The concept of stress was introduced by Selye [20] in 1936, but is still a controversial subject among people involved with animal production, from workers to the scientific community, perhaps because of the commonly established relationship between stress and animal welfare [21]. Cortisol is one of the most common stress indicators measured [22] and cortisol response to stress has been shown to vary between individuals as well as fluctuate during pre-slaughter handling [23].

Livestock meat and carcass quality characteristics are governed by several intrinsic and extrinsic factors [24]. The intrinsic factors that affect meat quality in ruminants include species, breed, age, weight at slaughter and gender (male, female, castrated). Similarly, extrinsic factors affecting the meat quality include stress (environmental effects, transportation and handling), diet and weaning [5]. Animals respond to the stressors faced during transport by making behavioral, immunological, hematological and metabolic changes [25], which may impair slaughter performance, and carcass and meat quality [26].

Many authors have investigated the effects of different factors, such as journey, transport and lairage duration [14, 27, 28], environmental conditions [29], welfare [30] and stocking density [31]. The results found by Toldrá [32] show that when an animal is stressed before slaughter, the resultant meat quality often suffers as a result. Pre-slaughter stress may result in the development of dark-cutting beef because of depletion of antemortem muscle glycogen stores and less post-mortem lactic acid accumulation [33]. Pre-slaughter stress can be roughly divided into two types: (1) long-term (chronic), from the collection, boarding and transportation stages; (2) short-term (acute), regarding management stages at the slaughterhouse (selection, waiting and driving at slaughter) $[34,35]$. Pre-slaughter heat stress must be minimized to the greatest degree which is possible to minimize PSE defects in broiler breast meat, the most valuable animal cut [36]. Trocino et al. [28] showed increased meat $\mathrm{pH}$ and $\mathrm{WHC}$ in rabbits subjected to long journeys. Holinger et al. [37] point out that carcasses of stress-exposed pigs had thicker backfat, lower lean meat percentage and different fatty acid composition of the adipose tissue.

It is important to highlight that thermal stress directly affects the development of animals, since it 
compromises the maintenance of homeothermy. Due to this, a physiological imbalance occurs that is caused by adverse temperatures and air relative humidity, either during rearing or at the time of slaughter, affecting the muscle glycogen reserves that are responsible for the development of post-mortem biochemical reactions that determine the meat quality and its functional properties.

Dokmanović et al. [38] correlated different categories of animal stresses, meat quality, and carcass quality characteristics in pigs and found that cortisol affected the carcass quality. High cortisol values in beef cattle resulted in high $\mathrm{pH}$ but cooking loss values were still within the normal range [39]. After arrival at the slaughterhouse, two important factors that may affect the level of stress in pigs and consequently pork quality, are lairage time and handling procedure immediately prior to slaughter [40]. Also, long lairage time proved to be a more stressful procedure and had a detrimental effect on carcass quality of pigs [40].

Heat is one of the most important environmental stressors for the poultry industry in the world [41]. Impacts of stress induced by high temperatures lead to a series of consequences for productivity, with higher water consumption and lower feed consumption, which directly affects feed conversion, growth rate, carcass yield and meat quality for organoleptic properties [6].

According to Wang et al. [36] heat stress increased the production of lactate in muscle, which in turn increased the rate of $\mathrm{pH}$ decline and subsequently decreased the quality of breast meat and increased the proportion of PSE meat of broiler chickens. Heat stress also reduces the muscle $\mathrm{pH}$ which in turn affects all the physicochemical attributes such as cooking loss, WHC, meat color and shear force [42].

Due to the changes that occur during the process of transformation of the live tissue muscle in consumable meat, it should be stressed that inadequate conditions of general environment offered to the animal, which can result in its stress, may lead to the formation of low quality products and rejection by the consumer.

Stress can significantly compromise meat quality, and among the main meat quality evaluation parameters that stand out are color-luminosity $\left(L^{*}, a^{*}, b^{*}\right)$ [43], $\mathrm{pH}$ [44], WHC [45], tenderness (shear force) [46] and lipid and protein oxidation [47]. Table 1 shows different stressor agents can affect meat quality in the species.

Table 1 Stress factors that affect meat quality of poultry, pigs, cattle, sheep, calves and lamb.

\begin{tabular}{|c|c|c|c|}
\hline Stressor agent & Species & Effects observed on meat quality & Reference \\
\hline \multirow{5}{*}{ Heat stress } & \multirow{5}{*}{ Poultry } & $\begin{array}{l}\text { Higher incidence of pale, soft, exudative (PSE) meat and decrease in } \\
\text { the } a^{*} \text { value of meat; }\end{array}$ & $\begin{array}{l}\text { Tankson et al. [48]; Dai et } \\
\text { al. [49]; Vaz et al. [50] }\end{array}$ \\
\hline & & Increased the rate of $\mathrm{pH}$ decline and incidence of PSE meat; & Wang et al. [36] \\
\hline & & Higher $L^{*}$ value; & Zhang et al. [46] \\
\hline & & Developed PSE or dark, firm, dry (DFD) breasts; & Gotardo et al. [51] \\
\hline & & Higher lipid oxidation. & Vaz et al. [50] \\
\hline \multirow[t]{2}{*}{ Cold stress } & \multirow[t]{2}{*}{ Poultry } & $\begin{array}{l}\text { Acute demands on energy metabolism and increases } \\
\text { glycogenolysis, which may result in meat with DFD characteristics; }\end{array}$ & Dadgar et al. $[52,53]$ \\
\hline & & Increase of $\mathrm{pH}$ and decrease of $L^{*}$ value. & Napper et al. [43] \\
\hline Acute stress & Cattle & Tougher Warner-Bratzler shear force (WBSF). & Zhao et al. [54] \\
\hline Fighting & Pigs & $\begin{array}{l}\text { Increased plasma levels of cortisol, adrenaline and metabolites, and } \\
\text { meat ultimate } \mathrm{pH} \text { increases proportionally to fighting levels. }\end{array}$ & $\begin{array}{l}\text { Fernandez et al. [55]; } \\
\text { Terlouw et al. }[56]\end{array}$ \\
\hline \multirow{5}{*}{$\begin{array}{l}\text { Transport and } \\
\text { lairage }\end{array}$} & \multirow[t]{2}{*}{ Cattle } & $\begin{array}{l}\text { Lairage decreased ultimate } \mathrm{pH} \text {; bulls subjected to } 24 \text { h lairage had } \\
\text { the lowest } L^{*}, b^{*} \text { and } H^{*} \text { values; lairage time had no effects on water } \\
\text { holding capacity (WHC), cooking loss and shear force values. }\end{array}$ & Teke et al. [57] \\
\hline & & Greater WBSF. & Gruber et al. [58] \\
\hline & \multirow{3}{*}{ Pigs } & $\begin{array}{l}\text { A stronger increase in salivary cortisol and their meat had more drip } \\
\text { loss (DL); }\end{array}$ & $\begin{array}{l}\text { Teke et al. [57]; Geverink } \\
\text { et al. [59] }\end{array}$ \\
\hline & & Transport time significantly affected DL, pH and meat color; & Chai et al. [60] \\
\hline & & Highest WBSF. & Lukić et al. [61] \\
\hline
\end{tabular}


(Table 1 continued)

\begin{tabular}{|c|c|c|c|}
\hline Stressor agent & Species & Effects observed on meat quality & Reference \\
\hline \multirow{5}{*}{$\begin{array}{l}\text { Slaughter and } \\
\text { Pre-slaughter }\end{array}$} & Poultry & Altered ultimate $\mathrm{pH}$ of thigh meat; & $\begin{array}{l}\text { Debut et al. [62]; Berri et } \\
\text { al. [63] }\end{array}$ \\
\hline & Pigs & Higher ultimate $\mathrm{pH}$ & Terlouw et al. [56] \\
\hline & Calves and Cattle & Higher ultimate $\mathrm{pH}$ & $\begin{array}{l}\text { Lensink et al. } \quad[64] \\
\text { Mounier et al. }[65]\end{array}$ \\
\hline & Lambs & $\begin{array}{l}\text { Increased the rate of } \mathrm{pH} \text { decline and ultimate } \mathrm{pH} \text {, as well as } \\
\text { the ability of muscle to hold water; }\end{array}$ & $\begin{array}{l}\text { Simmons et al. [66]; } \\
\text { Bond and Warner [67] }\end{array}$ \\
\hline & Lambs & Increases in DL. & Bond and Warner [67] \\
\hline Higher noise & Pigs & Significant negative effect on meat initial $\mathrm{pH}\left(\mathrm{pH}_{\mathrm{i}}\right)$ & Van de Perre et al. [68] \\
\hline \multirow{2}{*}{$\begin{array}{l}\text { Food/water } \\
\text { deprivation/fasting }\end{array}$} & Poultry & $\begin{array}{l}\text { Increased muscle } \mathrm{pH} \text { and increased sarcomere at } \\
\text { post-mortem } 0 \mathrm{~h} \text {, while decreased at post-mortem } 10 \mathrm{~h} \text {; }\end{array}$ & Wang et al. [69] \\
\hline & Lambs & $\begin{array}{l}\text { Tenderness scores varied significantly between the } 0 \mathrm{~h} \text { and } \\
48 \mathrm{~h} \text { groups. }\end{array}$ & Karaca et al. [10] \\
\hline Stunning & Poultry & $\begin{array}{l}\text { Affected breast meat color by decreasing } a * \text { and } 9 \mathrm{~d}, 150 \mathrm{~V} \text {, } \\
60 \mathrm{~Hz} \text { stunning reduced lipid oxidation in breast meat. }\end{array}$ & Xu et al. [70] \\
\hline
\end{tabular}

\section{The Stress Influence on Meat Quality} Parameters

\subsection{Color}

Color is one of the most important sensory attributes used to evaluate the quality of products and first criterion consumers use to judge meat quality and acceptability [71]. The main pigment responsible for meat color is myoglobin, a protein present in the sarcoplasm of the muscle fiber [35].

According to Mir et al. [72], light scattering affects meat lightness $\left(L^{*}\right)$ in a fashion inverse to that caused by heme pigment concentration, having a minimal effect on meat redness $\left(a^{*}\right)$ and yellowness $\left(b^{*}\right)$. It could be argued that appearance is the most important quality attribute of cooked or raw poultry meat because consumers associate it with the product's freshness, and they may decide whether or not to buy the product based solely on their opinion of its attractiveness [72]. In general, meat with a higher proportion of red fibers has a higher concentration of myoglobin, which is related to the predominance of aerobic (oxidative) metabolism, and a red color (greater than $L^{*}$ ) and darker (lower $L^{*}$ ) [35]. According to Zhang et al. [46], high ambient temperature had a significant influence on broiler meat quality. The meat color data showed that the meat of the breast and thigh of broilers subjected to constant high temperature presented higher $L^{*}$. A significant increase in the red content $\left(a^{*}\right)$ was observed by Vaz et al. [50] in the chests of birds that remained in the warm environment for $48 \mathrm{~h}$ and $72 \mathrm{~h}$, compared with birds that were not exposed to such stress. These authors suggest that a lower incidence of pale breast meat was found in birds raised under the heat stress conditions.

Extreme anomalous conditions include PSE and DFD meat, which are responsible for considerable economic losses in the industry [35]. The DFD meat, of dark color (dark), firm texture (firm) and extremely non-exudative (dry), is observed with some frequency in cattle, and can also be found in swine and birds. On the other hand, PSE is reported as the main anomalies in swine and birds [35]. The difference between "PSE" and "DFD" is that the former is associated with stress during a short time, just before slaughter, while DFD is closely linked to long-term stress before slaughter without the occurrence of adequate carbohydrate replacement in the body [73].

In a study conducted by Gotardo et al. [51], these inequalities indicate that, under a heat stress period of $1 \mathrm{~h} / \mathrm{d}$, broiler chickens at different stages of management will develop PSE or DFD breasts. Soares et al. [74] have proposed the following criteria for the classification of breast meat into quality categories: $L^{*}$ $\geq 53$ means a PSE meat, $L^{*} \leq 44$ means a DFD and 44 $<L^{*}<53$ means a normal meat. 
PSE meat is the result of accelerated post-mortem glycolysis, which results in a rapid post-mortem decline in $\mathrm{pH}$ while carcass temperatures are still high. Among the environmental factors to induce occurrence of PSE meat, ante-mortem stress, heat stress at the end of the growth or pre-slaughter phase and methods of stunning in the slaughterhouse seem to play the main role $[72,73]$. Van de Perre et al. [68] reported that in the summer, the risk of PSE in pigs is almost double the risk in winter, as these animals are sensitive to high temperatures. The apparent pale color in poultry meat is associated with lower pH [36]. PSE can be detected by combining $\mathrm{pH}$ values (below 5.8 ) and color ( $L^{*}$ value above 52) measured $24 \mathrm{~h}$ post-slaughter $[75,76]$.

It is known that DFD meat is a problem caused by chronic stress before slaughter, which depletes glycogen levels. The incidence of DFD meat is observed when the $\mathrm{pH}$ remains above normal, since the water retention capacity of the muscle proteins is very high, neither fibers are swollen by filling with sarcoplasmic fluids and their dispersed surface is less light [73]. Poor handling of cattle prior to slaughter might lead to a high incidence of DFD meat $(6.22 \pm$ 0.10 ) and a low mean value of percent cooking loss $(22.5 \pm 3.25)[16]$. This type of change in meat is also observed in swine [77], broiler [76], sheep [78] and especially in cattle [79].

\subsection{The $p H$}

Stress has a direct effect on the quality and physical-chemical characteristics of the meat as it changes the $\mathrm{pH}$ drop pattern due to the rapid use of glucose when the animal is subjected to conditions that modify its well-being. The main critical points that contribute to this are events related to pre-slaughter handlings, such as transport [80].

According to Boudjellal et al. [81], the rate of $\mathrm{pH}$ drops, as well as the final $\mathrm{pH}$ of the meat after $24-48 \mathrm{~h}$, is quite variable. The $\mathrm{pH}$ drop is faster in pigs, intermediate in sheep and slower in cattle [82]. For cattle, glycolysis usually develops slowly; the initial $\mathrm{pH}$ at one-hour post-slaughter is around 7.0, drops to 6.4-6.8 after $5 \mathrm{~h}$, and to 5.5-5.9 after $24 \mathrm{~h}$. In pigs, the rate of dropping is higher, reaching values of 5.6-5.7 after 6-8 post-mortem hours and 5.3-5.7 after $24 \mathrm{~h}$ [82]. For DFD meat, $\mathrm{pH}$ drops gradually by only a few tenths during the first hour after slaughter, the meat with final $\mathrm{pH}$ value (after $24 \mathrm{~h}$ ) remains between 6.5 and 6.8. For reddish pink, firm and non-exudative (RFN) meat, $\mathrm{pH}$ drops approximately 7.0 in live muscle to $\sim 5.6$ after $6-8 \mathrm{~h}$ post-mortem, reaching a final $\mathrm{pH}$ between 5.5 and 5.7 (normal). For PSE meat, $\mathrm{pH}$ drops rapidly in the first post-mortem hour, for values lower than 5.8 in $45 \mathrm{~min}$, presenting a final $\mathrm{pH}$ between 5.4 and 5.6, or even lower values. For acidic meat, $\mathrm{pH}$ drops gradually, but with very low final value, close to 5.0. Dotted curves illustrate intermediate quality categories such as slightly dark meat and PSE (Fig. 1) [35].

Karunanayaka et al. [83] found a correlation between $\mathrm{pH}$ and $L^{*}$ values, the $L^{*}$ value increased as muscle $\mathrm{pH}$ decreased. Desai et al. [84] subjected broilers to short-term heat stress $\left(38{ }^{\circ} \mathrm{C}\right.$ for $\left.2 \mathrm{~h}\right)$ and found lower values of $\mathrm{pH}$ for breast meat at $15 \mathrm{~min}$ after death (for PSE meat than normal meat).

\subsection{WHC}

WHC is one of the important sensory qualities of meat [6]. It is defined as the ability of meat to hold its own or added water during the application of external forces such as cutting, heating, grinding and pressing, and is implicated in numerous technological processes in which water retention plays a major role $[60,61]$. WHC is directly related to muscle fiber density and according to Huff-Lonergan and Lonergan [85], the muscular structure is composed of several "compartments" from which drip could originate. These could include the space within the myofibril, the intracellular space outside the myofibril and the extracellular space, including the space between the muscle bundles. 


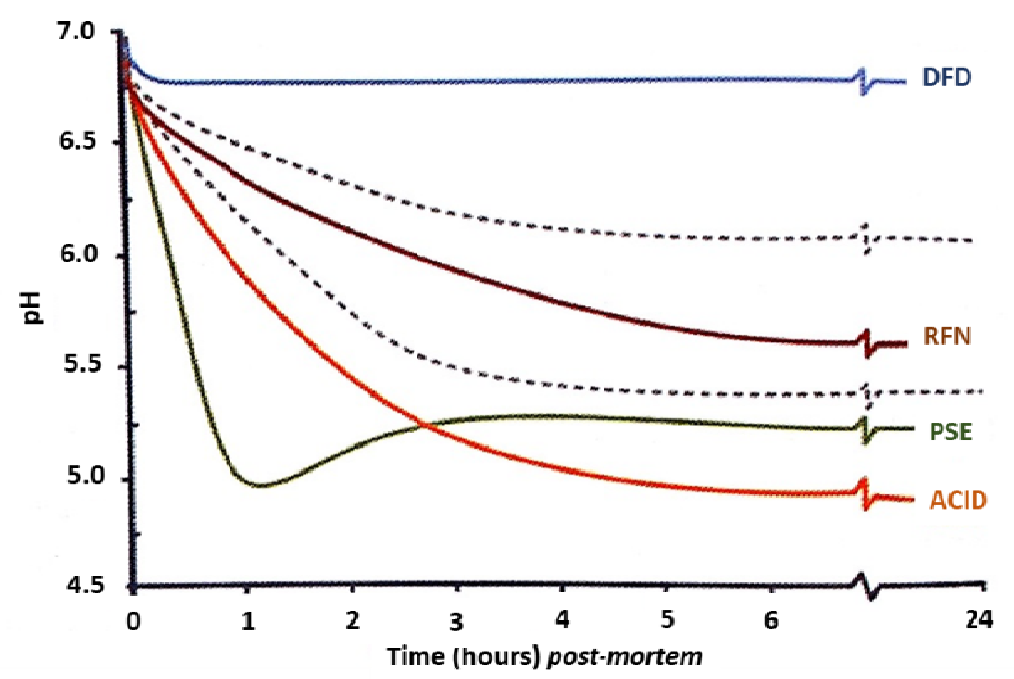

Fig. 1 Typical curves of post-mortem $\mathrm{pH}$ drops in pigs.

DFD: dark, firm, dry; PSE: pale, soft, exudative; RFN: reddish pink, firm and non-exudative.

Source: Briskey [86]. Adapted by Ramos and Gomide [35].

Drip loss (DL) can be used to determine WHC under no applied external force. To evaluate DL each sample is weighed then placed and suspended in an inflated plastic pot for $48 \mathrm{~h}$ at $4{ }^{\circ} \mathrm{C}$, after which they are reweighed [87]. DL is calculated as the percentage of weight loss: [(initial weight - final weight)/initial weight] $\times 100 \%$ [87]. WHC is $100 \%-$ DL $(\%)$.

According to Mir et al. [72], WHC has a direct bearing on the color and tenderness of meat, and is among the most important functional properties of raw meat. A study showed that cyclic heat stress (32.0, 21.0 and $32{ }^{\circ} \mathrm{C}$, for $10 \mathrm{~h} / \mathrm{d}$ ) had little impact on WHC of ground chicken leg meat [18]. Zhang et al. [45] evaluated the relationship of heat shock protein levels in swine muscles and meat quality and they observed a correlation between heat shock proteins and the WHC of the meat. DFD meat has a high WHC due to the $\mathrm{pH}$ being far from the isoelectric point of muscle proteins; in addition, with higher $\mathrm{pH}$, there is more incidence of deteriorating microorganisms [77].

Evaluating the effect of different periods $(0,24,48$ and $72 \mathrm{~h}$ ) of thermal stress on the physical and chemical quality of the meat of broilers, Vaz et al. [50] concluded that thermal stress affected the qualitative properties of the meat, especially lipid oxidation, WHC and shear force. Confirming the findings of some authors, Woelfel et al. [88] showed a tendency in reduction of WHC in meat from animals stressed prior to slaughter.

\subsection{Tenderness (Shear Force)}

Tenderness is probably the most important quality factor associated with consumer satisfaction of eating quality of poultry [72]. Tenderness is regarded as the most important sensory attribute affecting the meat acceptability [71].

Warner-Bratzler shear force (WBSF) is a direct indicator of the meat tenderness and eating meat quality [13]. According to Gomide [34], the shear force or softness is an attribute of the texture and the coarser the texture, the lower the softness. It is closely related to the amount of intramuscular water, and hence, WHC of the meat, so that the higher the water content in muscle, the greater the meat tenderness [89].

Previous research in beef has indicated that stress prior to slaughter is linked with a reduction in tenderness. Some studies have established a relationship between heat shock proteins and meat quality, including small heat shock proteins and their role in meat tenderness [90]. In a study with Angus cattle, Zhao et al. [54] subjected the animals to acute 
stress and the WBSF results showed that the stress group was much tougher than the control (nonstress) group. They also identified 137 differently expressed genes related to variations on stress status and beef quality. Physiological reactions of animals to transportation stress resulted in greater WBSF [58]. On the other hand, Vaz et al. [50] studying different conditions of thermal stress in broiler chickens at $42 \mathrm{~d}$ showed that the different temperatures (thermoneutral and stress conditions) and duration of stress influenced the meat tenderness, and that the meat of the birds that remained in thermal stress was more rigid; however, there was a lower post-mortem proteolytic potential, leading to a decrease in softness. Also, Lukić et al. [61] reported that pigs were affected by different durations of lairage time and WBSF was the highest in the group with $24 \mathrm{~h}$ lairage time.

\subsection{Lipid and Protein Oxidation}

Lipid oxidation is described as a deterioration of the oxygen-dependent meat quality of saturated and unsaturated fatty acids, contributing to flavor degradation and reduced product shelf life due to initiation of peroxidation [91]. Another characteristic of the lipid oxidation is to be an important quality indicator of fats, meat and meat products. Oxidized lipids not only change the color, aroma, flavor and texture of meat [92], they also result in rancid odor, unpleasant taste, loss of nutritional value, shortened shelf life and accumulation of toxic compounds which may be detrimental to the health of consumers [90, 91].

According to Reitznerová et al. [92], lipid oxidation in meat can be monitored through the value of thiobarbituric acid reactive substances (TBARS). Many studies have reported that broilers raised at high temperatures increased TBARS in plasma, organs and carcass [71, 72]. For this reason, these authors can conclude that the presented modified TBARS spectrophotometric method is suitable for monitoring the lipid oxidation processes in meat samples [92].
Higher lipid oxidation was observed in the meat of broilers that underwent thermal stress during periods of 24, 48 and $72 \mathrm{~h}$ compared to those without thermal stress [50]. In this way the quality of this meat will be inferior, since the lipid oxidation is one of the major causes of deterioration, contributing to the reduction of the useful life of the products [91].

Protein oxidation is described as the covalent modification of a protein, induced by reactive oxygen species or reaction with secondary byproducts of oxidative stress, which occurs through a free radical chain reaction, as well as oxidation of lipids in the muscles [47]. Oxidation of oxymyoglobin to metmyoglobin results in meat discoloration, while lipid oxidation leads to the production of off-flavor and decreases nutritional values of meat and meat products [47].

\section{Conclusions}

It is necessary to consider animal welfare in the ante-mortem period and during slaughter, in order to obtain a higher yield and use of carcass, and post-mortem processes to guarantee better quality of the produced meat.

Producing and processing high-quality meat is a challenge since it is necessary to apply methods that promote comfort in a complete sense, in a way that minimizes inducing significant stress. Based on the results presented it is remarkable that stress alters the meat quality, compromising the main attributes that involve it, like color, $\mathrm{pH}$, WHC, WBSF, lipid oxidation, among others. It is necessary to avoid or reduce stress caused during the production of the animals to ensure a high-quality meat, resulting in greater profitability for the producer.

\section{Acknowledgments}

The authors are thankful to Center for Research in Environment and Agroindustry Systems Engineering (AMBIAGRO) and Department of Agricultural Engineering at the Federal University of Viçosa 
(UFV). The authors also thank the Brazilian Government to provide support and funds to carry out this research. This study was financed in part by the Coordenação de Aperfeiçoamento de Pessoal de Nível Superior (CAPES) Finance Code 001, Conselho Nacional de Desenvolvimento Científico e Tecnológico (CNPq), and Fundação de Amparo à Pesquisa do Estado de Minas Gerais (FAPEMIG).

\section{References}

[1] FAO. 2015. Statistical Yearbook. Food and Agriculture Organization of the United Nations (FAO), Rome, Italy.

[2] Brown, S., and Madison, D. 2019. 2019 Baseline Update for Livestock and Dairy Markets. August 28, 2019. University of Missouri. Accessed September 30, 2019. https://amap.missouri.edu/wp-content/uploads/2019/08/A ugust-2019-AMAP-Baseline-update-1.pdf.

[3] Melo, A. F., Moreira, J. M., Ataídes, D. S., Aparecida, R., Guimarães, M., Loiola, J. L., and Oliveira, R. Q. 2016. "Factors Influencing Beef Quality: A Review." Pubvet. 10: 785-94. (in Portuguese)

[4] Hocquette, J. F., Richardson, R. I., Prache, S., Medale, F., Duffy, G., and Scollan, N. D. 2005. "The Future Trends for Research on Quality and Safety of Animal Products." Ital. J. Anim. Sci. 4: 49-72.

[5] Guerrero, A., Valero, M. V., Campo, M. M., and Sañudo, C. 2013. "Some Factors That Affect Ruminant Meat Quality: From the Farm to the Fork. Review." Acta Sci. 35: 335-47.

[6] Song, D. J., and King, A. J. 2015. "Effects of Heat Stress on Broiler Meat Quality." Worlds. Poult. Sci. J. 71: 701-9.

[7] Castellini, C., Mattioli, S., Piottoli, L., Mancinelli, A. C., Ranucci, D., Branciari, R., Amato, M. G., and Dal Bosco, A. 2016. "Effect of Transport Length on in Vivo Oxidative Status and Breast Meat Characteristics in Outdoor-Reared Chicken Genotypes." Ital. J. Anim. Sci. 15: 191-9.

[8] Rimoldi, S., Lasagna, E., Sarti, F. M., Marelli, S. P., Cozzi, M. C., Bernardini, G., and Terova, G. 2015. "Expression Profile of Six Stress-Related Genes and Productive Performances of Fast and Slow Growing Broiler Strains Reared under Heat Stress Conditions." Meta Gene 6: 17-25.

[9] Karakaya, M., Bayrak, E., and Ulusoy, K. 2011. "Use of Natural Antioxidants in Meat and Meat Products." J. Food Sci. Eng. 1: 1-10.

[10] Karaca, S., Erdoğan, S., Kor, D., and Kor, A. 2016. "Effects of Pre-slaughter Diet/Management System and Fasting Period on Physiological Indicators and Meat
Quality Traits of Lambs.” Meat Sci. 116: 67-77.

[11] Ferguson, D. M., and Warner, R. D. 2008. "Have We Underestimated the Impact of Pre-slaughter Stress on Meat Quality in Ruminants?" Meat Sci. 80: 12-9.

[12] Faucitano, L. 2018. "Preslaughter Handling Practices and Their Effects on Animal Welfare and Pork Quality." J. Anim. Sci. 96: 728-38.

[13] Chulayo, A. Y., and Muchenje, V. 2013. "The Effects of Pre-slaughter Stress and Season on the Activity of Plasma Creatine Kinase and Mutton Quality from Different Sheep Breeds Slaughtered at a Smallholder Abattoir." Asian-Australasian J. Anim. Sci. 26: 1762-72.

[14] Chulayo, A. Y., Bradley, G., and Muchenje, V. 2016. "Effects of Transport Distance, Lairage Time and Stunning Efficiency on Cortisol, Glucose, HSPA1A and How They Relate with Meat Quality in Cattle.” Meat Sci. 117: 89-96.

[15] Kauffman, R. G., Wachholz, D., Henderson, D., and Lochner, J. V. 1978. "Shrinkage of PSE Normal and DFD Hams during Transit and Processing." J. Anim. Sci. 46: 1236-40.

[16] Frimpong, S., Gebresenbet, G., Bobobee, E., Aklaku, E., and Hamdu, I. 2014. "Effect of Transportation and Pre-slaughter Handling on Welfare and Meat Quality of Cattle: Case Study of Kumasi Abattoir, Ghana." Vet. Sci. 1: 174-91.

[17] Holm, C. G. P., and Fletcher, D. L. 1997. "Antemortem Holding Temperatures and Broiler Breast Meat Quality." J. Appl. Poult. Res. 6: 180-4.

[18] Kim, H. W., Kim, J. H., Yan, F., Cheng, H. W., and Kim, Y. H. B. 2017."Effects of Heat Stress and Probiotic Supplementation on Protein Functionality and Oxidative Stability of Ground Chicken Leg Meat during Display Storage." J. Sci. Food Agric. 97:5343-51.

[19] Pighin, D. G., Cunzolo, S. A., Zimerman, M., Pazos, A. A., Domingo, E., Pordomingo, A. J., and Grigioni, G. 2013. "Impact of Adrenaline or Cortisol Injection on Meat Quality Development of Merino Hoggets." J. Integr. Agric. 12: 1931-6.

[20] Selye, H. A. 1936. "Syndrome Produced by Diverse Nocuous Agents." Nature 138: 32.

[21] Brossi, C., Contreras-Castillo, C. J., Amazonas, E. A., and Menten, J. F. M. 2009. "Thermal Stress during Pre-slaughter in Broiler Chickens." Ciência Rural. 39: 1296-305. (in Portuguese)

[22] Shaw, F. D., and Tume, R. K. 1992. "The Assessment of Pre-slaughter and Slaughter Treatments of Livestock by Measurement of Plasma Constituents: A Review of Recent Work." Meat Sci. 32: 311-29.

[23] Fisher, A. D., Niemeyer, D. O., Lea, J. M., Lee, C., Paull, D. R., Reed, M. T., and Ferguson, D. M. 2010. "The Effects of 12, 30, or 48 Hours of Road Transport on the 
Physiological and Behavioral Responses of Sheep." J. Anim. Sci. 88: 2144-52.

[24] Archana, P. R., Sejian, V., Ruban, W., Bagath, M., Krishnan, G., Aleena, J., Manjunathareddy, G. B., Beena, V., and Bhatta, R. 2018. "Comparative Assessment of Heat Stress Induced Changes in Carcass Traits, Plasma Leptin Profile and Skeletal Muscle Myostatin and HSP70 Gene Expression Patterns between Indigenous Osmanabadi and Salem Black Goat Breeds." Meat Sci. 141: 66-80.

[25] Broom, D. M., and Fraser, A. F. 2012. Domestic Animal Behaviour and Welfare, 5th ed. Wallingford: CABI, 472.

[26] Schwartzkopf-Genswein, K. S., Faucitano, L., Dadgar, S., Shand, P., González, L. A., and Crowe, T. G. 2012. "Road Transport of Cattle, Swine and Poultry in North America and Its Impact on Animal Welfare, Carcass and Meat Quality: A Review." Meat Sci. 92: 227-43.

[27] Jama, N., Maphosa, V., Hoffman, L. C., and Muchenje, V. 2016. "Effect of Sex and Time to Slaughter (Transportation and Lairage Duration) on the Levels of Cortisol, Creatine Kinase and Subsequent Relationship with Pork Quality." Meat Sci. 116: 43-9.

[28] Trocino, A., Zomeño, C., Birolo, M., Di Martino, G., Stefani, A., Bonfanti, L., Bertotto, D., Gratta, F., and Xiccato, G. 2018. "Impact of Pre-slaughter Transport Conditions on Stress Response, Carcass Traits, and Meat Quality in Growing Rabbits." Meat Sci. 146: 68-74.

[29] Cesari, V., Zucali, M., Bava, L., Gislon, G., Tamburini, A., and Toschi, I. 2018. "Environmental Impact of Rabbit Meat: The Effect of Production Efficiency." Meat Sci. 145: 447-54.

[30] Aghwan, Z. A., Bello, A. U., Abubakar, A. A., Imlan, J. C., and Sazili, A. Q. 2016. "Efficient Halal Bleeding, Animal Handling, and Welfare: A Holistic Approach for Meat Quality." Meat Sci. 121: 420-8.

[31] Loponte, R., Secci, G., Mancini, S., Bovera, F., Panettieri, V., Nizza, A., Di Meo, C., Piccolo, G., and Parisi, G. 2018. "Effect of the Housing System (Free-Range vs. Open Air Cages) on Growth Performance, Carcass and Meat Quality and Antioxidant Capacity of Rabbits." Meat Sci. 145: 137-43.

[32] Toldrá, F. 2017. "Lawrie's Meat Science." In Woodhead Publishing Series in Food Science, Technology and Nutrition, 8th ed. Sawston: Woodhead Publishing, 730.

[33] Lu, X., Zhang, Y., Qin, L., Ma, W., Zhu, L., and Luo, X. 2018. "Association of Ultimate $\mathrm{pH}$ and Stress-Related Blood Variables in Cattle." Meat Sci.139: 228-30.

[34] Gomide, L. A. M. 2014. Technology of Slaughter and Typing of Carcasses, 2th ed. Viçosa: Editora UFV, 336. (in Portuguese)

[35] Ramos, E. M., and Gomide, L. A. M. 2017. Evaluation of Meat Quality: Fundamentals and Methodologies, 2th ed.
Viçosa: Editora UFV, 473. (in Portuguese)

[36] Wang, R. H., Liang, R. R., Lin, H., Zhu, L. X., Zhang, Y. M., Mao, Y. W., Dong, P. C., Niu, L. B., Zhang, M. H., and Luo, X. 2017. "Effect of Acute Heat Stress and Slaughter Processing on Poultry Meat Quality and Postmortem Carbohydrate Metabolism.” Poult. Sci. 96: 738-46.

[37] Holinger, M., Früh, B., Stoll, P., Pedan, V., Kreuzer, M., Bérard, J., and Hillmann, E. 2018. "Long-Term Effects of Castration, Chronic Intermittent Social Stress, Provision of Grass Silage and Their Interactions on Performance and Meat and Adipose Tissue Properties in Growing-Finishing Pigs.” Meat Sci. 145: 40-50.

[38] Dokmanovic, M., Baltic, M. Z., Duric, J., Ivanovic, J., Popovic, L., Todorovic, M., Markovic, R., and Pantic, S. 2015. "Correlations among Stress Parameters, Meat and Carcass Quality Parameters in Pigs.” Asian-Australasian J. Anim. Sci. 28: 435-41.

[39] Maghfiroh, K., Latif, H., and Santoso, K. 2014. "Cortisol Hormone Concentration and Meat Quality of Beef Cattle Stunned by Captive Bolt Stun Gun before Slaughtering." Media Peternak 37: 155-60.

[40] Dokmanović, M., Velarde, A., Tomović, V., Glamočlija, N., Marković, R., Janjić, J., and Baltić, M. Z. 2014. "The Effects of Lairage Time and Handling Procedure Prior to Slaughter on Stress and Meat Quality Parameters in Pigs." Meat Sci. 98: 220-6.

[41] Zaboli, G., Huang, X., Feng, X., and Ahn, D. U. 2018. "How Can Heat Stress Affect Chicken Meat Quality? A Review." Poult. Sci. 98: 1-6.

[42] Gregory, N. G. 2010. "How Climatic Changes Could Affect Meat Quality." Food Res. Int. 43: 1866-73.

[43] Napper, S., Dadgar, S., Arsenault, R. J., Trost, B., Scruten, E., Kusalik, A., and Shand, P. 2015. "Induction of Tissue- and Stressor-Specific Kinomic Responses in Chickens Exposed to Hot and Cold Stresses." Poult. Sci. 94:1333-45.

[44] Rouhalamini, S. M., Salarmoini, M., and Asadi-Karam, G. 2014. "Effect of Zinc Sulfate and Organic Chromium Supplementation on the Performance, Meat Quality and Immune Response of Japanese Quails under Heat Stress Conditions.” Poult. Sci. J. 2: 165-81.

[45] Zhang, M., Wang, D., Geng, Z., Bian, H., Liu, F., Zhu, Y., and $\mathrm{Xu}, \mathrm{W} .2014$. "The Level of Heat Shock Protein 90 in Pig Longissimus Dorsi Muscle and Its Relationship with Meat pH and Quality." Food Chem. 165: 337-41.

[46] Zhang, Z. Y., Jia, G. Q., Zuo, J. J., Zhang, Y., Lei, J., Ren, L., and Feng, D. Y. 2012. "Effects of Constant and Cyclic Heat Stress on Muscle Metabolism and Meat Quality of Broiler Breast Fillet and Thigh Meat." Poult. Sci. 91: 2931-7.

[47] Zhang, W., Xiao, S., and Ahn, D. U. 2013. "Protein 
Oxidation: Basic Principles and Implications for Meat Quality." Crit. Rev. Food Sci. Nutr. 53: 1191-201.

[48] Tankson, J. D., Vizzier-Thaxton, Y., Thaxton, J. P., May, J. D., and Cameron, J. A. 2001. "Stress and Nutritional Quality of Broilers." Poult. Sci. 80: 1384-9.

[49] Dai, S. F., Wang, L. K., Wen, A. Y., Wang, L. X., and Jin, G. M. 2009. "Dietary Glutamine Supplementation Improves Growth Performance, Meat Quality and Colour Stability of Broilers under Heat Stress." Br. Poult. Sci. 50: 333-40.

[50] Vaz, A. B. S., Ganecco, A. G., Melo, J. L. M., Dourado, R.T., Berton, M. P., Moreno, G. M. B., Boiago, M. M., Borba, H., Miyagusku, L., and Souza, P. A. 2016. "Broiler Meat Quality Evaluation Created in Simulated Conditions of Heat." J. Food Process. Technol. 7: 1-8.

[51] Gotardo, L. R. M., Vieira, P. B., Marchini, C. F. P., Nascimento, M. R. B. M., Antunes, R. C., Guimarães, E. C., Bueno, J. P., and Santos, D. B. 2015. "Cyclic Heat Stress in Broilers and Their Effects on Quality of Chicken Breast Meat." Acta Sci. Vet. 55: 1-5.

[52] Dadgar, S., Lee, E. S., Leer, T. L. V., Burlinguette, N., Classen, H. L., Crowe, T. G., and Shand, P. J. 2010. "Effect of Microclimate Temperature during Transportation of Broiler Chickens on Quality of the Pectoralis Major Muscle." Poult. Sci. 89: 1033-41.

[53] Dadgar, S., Lee, E. S., Crowe, T. G., Classen, H. L., and Shand, P. J. 2012. "Characteristics of Cold-Induced Dark, Firm, Dry Broiler Chicken Breast Meat.” Br. Poult. Sci. 53: 351-9.

[54] Zhao, C., Tian, F., Yu, Y., Luo, J., Mitra, A., Zhan, F., Hou, Y., Liu, G., Zan, L., Updike, M.S., and Song, J. 2012. "Functional Genomic Analysis of Variation on Beef Tenderness Induced by Acute Stress in Angus Cattle." Comp. Funct. Genomics, Article ID 756284. doi:10.1155/2012/756284.

[55] Fernandez, X., Meunier-Salaün, M. C., and Mormede, P. 1994. "Agonistic Behavior, Plasma Stress Hormones, and Metabolites in Response to Dyadic Encounters in Domestic Pigs: Interrelationships and Effect of Dominance Status." Physiol. Behav. 56: 841-7.

[56] Terlouw, E. M. C., Porcher, J., and Fernandez, X. 2005. "Repeated Handling of Pigs During Rearing. II. Effect of Reactivity to Humans on Aggression during Mixing and on Meat Quality." J. Anim. Sci. 83: 1664-72.

[57] Teke, B., Akdag, F., Ekiz, B., and Ugurlu, M. 2014. "Effects of Different Lairage Times after Long Distance Transportation on Carcass and Meat Quality Characteristics of Hungarian Simmental Bulls." Meat Sci. 96: 224-9.

[58] Gruber, S. L., Tatum, J. D., Engle, T. E., Chapman, P. L., Belk, K. E., and Smith, G. C. 2010. "Relationships of Behavioral and Physiological Symptoms of Preslaughter Stress to Beef Longissimus Muscle Tenderness.” J. Anim.
Sci. 88: 1148-59.

[59] Geverink, N. A., Jong, I. C., Lambooij, E., Blokhuis, H. J., and Wiegant, V. M. 1999. "Influence of Housing Conditions on Responses of Pigs to Preslaughter Treatment and Consequences for Meat Quality." Can. J. Anim. Sci. 79: 285-91.

[60] Chai, J., Xiong, Q., Zhang, C. X., Miao, W., Li, F. E., Zheng, R., Peng, J., and Jiang, S. W. 2010. "Effect of Pre-slaughter Transport Plant on Blood Constituents and Meat Quality in Halothane Genotype of NN Large White $\times$ Landrace Pigs." Livest. Sci. 127: 211-7.

[61] Lukić, B., Kušec, I. D., Ovničević’s, D., Mandić, S., Đidara, M., Šperanda, M., and Kušec, G. 2014. "Stress Indicators and Meat Quality of Pigs Affected by Different Durations of Lairage Time." Acta Agrar. Kaposváriensis. 18: 109-14.(in Hungarian)

[62] Debut, M., Berri, C., Baeza, E., Sellier, N., Arnould, C., Guemene, D., Jehl, N., Boutten, B., Jego, Y., Beaumont, C., and Le Bihan-Duval, E. 2003. "Variation of Chicken Technological Meat Quality in Relation to Genotype and Preslaughter Stress Conditions." Poult. Sci. 82: 1829-38.

[63] Berri, C., Debut, M., Santé-Lhoutellier, V., Arnould, C., Boutten, B., Sellier, N., Baéza, E., Jehl, N., Jégo, Y., Duclos, M.J., and Le Bihan-Duval, E. 2005. "Variations in Chicken Breast Meat Quality: Implications of Struggle and Muscle Glycogen Content at Death.” Br. Poult. Sci. 46: 572-9.

[64] Lensink, B. J., Fernandez, X., Cozzi, G., Florand, L., and Veissier, I. 2001. "The Influence of Farmers' Behavior on Calves' Reactions to Transport and Quality of Veal Meat." J. Anim. Sci. 79: 642-52.

[65] Mounier, L., Dubroeucq, H., Andanson, S., and Veissier, I. 2006. "Variations in Meat Ph of Beef Bulls in Relation to Conditions of Transfer to Slaughter and Previous History of the Animals." J Anim Sci. 84: 1567-76.

[66] Simmons, N. J., Young, O. A., Dobbie, P. M., Singh, K., Thompson, B. C., and Speck, P. A. 1997. "Post-Mortem Calpain-System Kinetics in Lamb: Effects of Clenbuterol and Preslaughter Exercise." Meat Sci. 47: 135-46.

[67] Bond, J. J., and Warner, R. D. 2007. "Ion Distribution and Protein Proteolysis Affect Water Holding Capacity of Longissimus Thoracis et Lumborum in Meat of Lamb Subjected to Antemortem Exercise." Meat Sci. 75: 406-14.

[68] Van de Perre, V., Permentier, L., De Bie, S., Verbeke, G., and Geers, R. 2010. "Effect of Unloading, Lairage, Pig Handling, Stunning and Season on $\mathrm{pH}$ of Pork." Meat Sci. 86: 931-7.

[69] Wang, S., Li, C., Xu, X., and Zhou, G. 2013. "Effect of Fasting on Energy Metabolism and Tenderizing Enzymes in Chicken Breast Muscle Early Postmortem.” Meat Sci. 93: 865-72. 
[70] Xu, L., Zhang, H., Yue, H., Wu, S., Yang, H., Qi, G., and Wang, Z. 2018. "Low-Current and High-Frequency Electrical Stunning Increased Oxidative Stress, Lipid Peroxidation, and Gene Transcription of the Mitogen-Activated Protein Kinase/Nuclear Factor-Erythroid 2-Related Factor 2/Antioxidant Responsive Element (MAPK/Nrf2/ARE) Signaling Pathway in Breast Muscle of Broilers." Food Chem. 242: 491-6.

[71] Karthika, S., Chandirasekaran, V., and Sureshkumar, S. 2016. "Sensory Attributes of Namakkal Quail-1 Meat." Int. J. of Adv. Vet. Sci. and Tec. 5: 266-9.

[72] Mir, N. A., Rafiq, A., Kumar, F., Singh, V., and Shukla, V. 2017. "Determinants of Broiler Chicken Meat Quality and Factors Affecting Them: A Review." J. Food Sci. Technol. 54: 2997-3009.

[73] Lawrie, R. A. 1998. "The Conversion of Muscle to Meat." In Lawrie's Meat Science, 6th ed., edited by Lawrie, R. A. Woodhead: Cambridge, 336.

[74] Soares, A. L., Lara, J. A. F., Ida, E. I., Guarnieri, P. D., Olivo, R., and Shimokomaki, M. 2002. "Variation in the Color of Brazilian Broiler Breast Fillet." International Congress of Meat Science and Technology 48: 540-1.

[75] Petracci, M., Bianchi, M., and Cavani, C. 2010. "Pre-slaughter Handling and Slaughtering Factors Influencing Poultry Product Quality." Worlds. Poult. Sci. J. 66: 17-26.

[76] Langer, R. O., Simões, G. S., Soares, A. L., Oba, A., Rossa, A., Shimokomaki, M., and Ida, E. I. 2010. "Broiler Transportation Conditions in a Brazilian Commercial Line and the Occurrence of Breast PSE (Pale, Soft, Exudative) Meat and DFD-Like (Dark, Firm, Dry) Meat." Braz. Arch. Biol. Technol. 53: 1161-7.

[77] Guàrdia, M. D., Estany, J., Balasch, S., Oliver, M. A., Gispert, M., and Diestre, A. 2005. "Risk Assessment of DFD Meat due to Pre-slaughter Conditions in Pigs." Meat Sci. 70: 709-16.

[78] Miranda-de la Lama, G. C., Sepúlveda, W. S., Villarroel, M., and María, G. A. 2013. "Attitudes of Meat Retailers to Animal Welfare tn Spain.”Meat Sci. 95: 569-75.

[79] Ponnampalam, E. N., Hopkins, D. L., Bruce, H., Li, D., Baldi, G., and Bekhit, A. E. 2017. "Causes and Contributing Factors to 'Dark Cutting' Meat: Current Trends and Future Directions: A Review." Compr. Rev. Food Sci. Food Saf. 16: 400-30.

[80] Alves, A. R., Figueiredo Júnior, J. P., Santana, M. H. M., Andrade, M. V. M., Lima, J. B. A., Pinto, L. S., and Ribeiro, L. M. 2016. "Effect of Stress on Quality of Animal Products." Pubvet. 10: 448-59. (in Portuguese)

[81] Boudjellal, A., Becila, S., Coulis, G., Herrera-Mendez, C.
H., Aubry, L., Lepetit, J., Harhoura, K., Sentandreu, M. A., Aït-Amar, H., and Ouali, A. 2008. "Is the pH Drop Profile Curvilinear and Either Monophasic or Polyphasic? Consequences on the Ultimate Bovine Meat Texture." African J. Agric. Res. 3: 195-204.

[82] Roça, R. O. 2001. Post-Mortem Modifications. São Paulo: São Paulo State University, 16.

[83] Karunanayaka, D. S., Jayasena, D. D., and Jo, C. 2016. "Prevalence of Pale, Soft, and Exudative (PSE) Condition in Chicken Meat Used For Commercial Meat Processing and Its Effect on Roasted Chicken Breast.” J. Anim. Sci. Technol. 58: 1-8.

[84] Desai, M. A., Jackson, V., Zhai, W., Suman, S. P., Nair, M. N., Beach, C. M., and Schilling, M. W. 2016. "Proteome Basis of Pale, Soft, and Exudative-Like (PSE-Like) Broiler Breast (Pectoralis Major) Meat." Poult. Sci. 95: 2696-706.

[85] Huff-Lonergan, E., and Lonergan, S. M. 2005. "Mechanisms of Water-Holding Capacity of Meat: The Role of Postmortem Biochemical and Structural Changes." Meat Sci. 71: 194-204.

[86] Briskey, E. J. 1964. "Etiological Status and Associated Studies of Pale, Soft, Exudative Porcine Musculature." Adv. Food Res. 13: 89-178.

[87] Honikel, K. O. 1998. "Reference Methods for the Assessment of Physical Characteristics of Meat." Meat Sci. 49: 447-57.

[88] Woelfel, R. L., Owens, C. M., Hirschler, E. M., Martinez-Dawson, R., and Sams, A. R. 2002. "The Characterization and Incidence of Pale, Soft, and Exudative Broiler Meat in a Commercial Processing Plant." Poult. Sci. 81: 579-84.

[89] Anadón, H. L. S. 2002. "Biological, Nutritional, and Processing Factors Affecting Breast Meat Quality of Broilers." Ph.D. thesis, Virginia Polytechnic Institute and State University.

[90] Lomiwes, D., Farouk, M. M., Wiklund, E., and Young, O. A. 2014. "Small Heat Shock Proteins and Their Role in Meat Tenderness: A Review." Meat Sci. 96: 26-40.

[91] Vercellotti, J. R., Angelo, A. J., and Spanier, A. M. 1992. "Lipid Oxidation in Foods: An Overview." J. Pure Appl. Chem. 64: 1959-64.

[92] Reitznerová, A., Uleková, M., Nagy, J., Marcinčák, S., Semjon, B., Čertík, M., and Klempová, T. 2017. "Lipid Peroxidation Process in Meat and Meat Products: A Comparison Study of Malondialdehyde Determination between Modified 2-Thiobarbituric Acid Spectrophotometric Method and Reverse-Phase High-Performance Liquid Chromatography." Molecules 22: $1-12$. 